\title{
KEGIATAN SUPERVISI PENDIDIKAN DALAM MENUNJANG KINERJA GURU DI TK ISLAM TIRTAYASA SERANG
}

\author{
Cucu Atikah \\ Program Studi PG-PAUD Universitas Sultan Ageng Tirtayasa, \\ Email: cucuatikah@untirta.ac.id
}

(Received: Mei 2018; Accepted: Mei 2018; Published: Juni 2018)

\begin{abstract}
Supervision activities are often conducted in the Islamic Kindergarten Tirtayasa because there is an indication of the low performance of teachers, especially newly appointed teachers. Generally lack the mastery of communication with learners and the principles of learning in TK.Tujuan want achieved in this study is to analyze and describe the activities of supervision of education in supporting the performance of teachers in the Islamic Kindergarten Tirtayasa Serang. The number of teachers in the Islamic TKT is 14 people. The results showed that the supervision of education activities conducted principals can support the performance of teachers.
\end{abstract}

Keywords: Supervision of education, performance, teacher.

\begin{abstract}
ABSTRAK
Kegiatan supervisi seringkali dilakukan di TK Islam Tirtayasa karena ada indikasi rendahnya kinerja guru, khususnya guru-guru yang baru diangkat. Umumnya kurang menguasai komunikasi dengan peserta didik dan prinsip-prinsip pembelajaran di TK.Tujuan yang ingin dicapai pada penelitian ini adalah untuk menganalisis dan mendeskripsikan tentang kegiatan supervisi pendidikan dalam menunjang kinerja guru di TK Islam Tirtayasa Serang. Jumlah guru di TK islam Tirtayasa 14 orang. Hasil penelitian menunjukkan bahwa kegiatan supervisi pendidikan yang dilakukan kepala sekolah dapat menunjang kinerja guru.
\end{abstract}

Kata Kunci : Supervisi pendidikan, kinerja, guru

\section{PENDAHULUAN}

Setiap pelaksanaan program pendidikan memerlukan adanya pengawasan atau supervisi. Pengawasan bertanggung jawab tentang keefektifan program itu. Oleh karena itu, supervisi haruslah meneliti ada atau tidaknya kondisi-kondisi yang akan memungkinkan tercapainya tujuan-tujuan pendidikan. Setelah kita mengetahui realita yang terjadi seperti yang sudah tersebut di atas,maka diperlukan sebuah penjelasa secara rinci dan mendetail tentang supervisi pendidikan agar para pendidik dapat memahami betapa perlu dan pentingnya supervisi pendidikan itu.

Supervisi merupakan suatu layanan dari atasan kepada bawahan dengan memberikan pengarahan guna mengembangkan kinerja menjadi lebih baik. Kegiatan supervisi disebut pula sebagai kegiatan mengawasi atau pengawasan. Pengawasan dalam rangka pengembangan di lembaga sekolah baik adanya. Karena dengan adanya pengawasan (supervisi), diharapkan lembaga pendidikan akan semakin berkembang. Mempelajari tujuan, prinsip, fungsi dan obyek dalam supervisi pendidikan menjadi penting dan wajib. Karena tanpa mengetahui hal dasar di atas, supervisi pendidikan tidak akan bisa diaplikasikan.

Konsep supervisi berbeda dengan pemeriksaan. Pemeriksaan melihat apa yang terjadi dalam kegiatan sedangkan pengawasan adalah melihat apa yang positif dan negatif. Adapun supervisi juga merupakan kegiatan 
pengawasan tetapi sifatnya lebih human, manusiawi. Kegiatan supervisi bukan mencaricari kesalahan tetapi lebih banyak mengandung unsur pembinnaan, agar kondisi pekerjaan yang sedang disupervisi dapat diketahui kekurangannya (bukan semata-mata kesalahannya) untuk dapat diberitahu bagian yang perlu diperbaiki. Supervisi dilakukan untuk melihat bagian mana dari kegiatan sekolah yg masih negatif untuk diupayakan menjadi positif, dan melihat mana yang sudah positif untuk ditingkatkan menjadi lebih positif lagi dan yang terpenting adalah pembinaannya

Orang yang melakukan supervisI disebut supervisor. Dibidang pendidikan disebut supervisor pendidikan. Menurut keputusan menteri pendidikan dan kebudayaan nomor 0134/0/1977, temasuk kategori supervisor dalam pendidikan adalah kepala sekolah, penelik sekolah, dan para pengawas ditingkat kabupaten/kotamadya, serta staff di kantor bidang yang ada di tiap provinsi. Supervisi pendidikan merupakan hal yang tak terpisahkan dalam penyelenggaran satuan pendidikan mulai dari Taman Kanak-kanak atau PAUD (Pendidikan Anak Usia Dini) hingga jenjang pendidikan tinggi setingkat Universitas. Supervisi bukan berarti mencari kelemahan pada tenaga pendidik dan tenaga kependidikan, namun supervisi pendidikan bersifat mengatur, mengarahkan, mengawasi, membina, serta memberikan evaluasi terhadap kinerja tenaga pendidik dan tenaga kependidikan serta hal-hal yang berhubungan dengan sistem pendidikan yang terkait dengan kurikulum, sarana dan prasarana, serta proses belajar mengajar yang berjalan di satuan pendidikan. Disadari atau tidak, dewasa ini supervisi pendidikan merupakan hal mutlak yang harus ada dalam satuan pendidikan guna mengetahui sejauh apa dan seperti apa berjalannya hal-hal yang terkait dengan pendidikan.

Mengingat pentingnya supervisi pendidikan, maka tak dapat dipungkiri lagi bahwa mengetahui dan mempelajari tentang Supervisi Pendidikan merupakan langkah awal yang sangat fundamental untuk mengetahui sejauh mana

perkembangan

dan

kemajuan pendidikan itu berjalan apakah target atau tujuan yang sudah direncanakan sudah mampu terlaksana atau belum, dan jika belum, melalui supervisi inilah diadakan pengawasan dan pembinaan

Jika supervisi dilaksanakan oleh kepala sekolah, maka ia harus mampu melakukan berbagai pengawasan dan pengendalian untuk meningkatkan kinerja tenaga pendidik dan tenaga kependidikan. Pengawasan dan pengendalian ini merupakan kontrol agar kegiatan pendidikan di sekolah terarah pada tujuan yang telah ditetapkan. Pengawasan dan pengendalian juga merupakan tindakan preventif untuk mencegah agar para tenaga pendidik dan tenaga kependidikan tidak melakukan penyimpangan dan lebih berhatihati dalam melaksanakan pekerjaannya. Khusus dalam penelitian ini supervisi yang dilakukan kepala sekolah terhadap kinerja para guru di TK Islam Tirtayasa serang.

\section{KAJIAN PUSTAKA}

\subsection{Pengertian Supervisi}

Supervisi merupakan salah satu strategi untuk memastikan bahwa seluruh langkah pada proses penyelenggaraan dan semua komponen hasil pendidikan yang akan dicapai memenuhi target, straegi manajemen yang terdapat dalam supervisi terdiri atas serangkaian kegiatan untuk memastikan bahwa mutu yang diharapkan dalam proses perencanaan, pelaksanaan kegiatan, dan evaluasi memenuhi standar yang telah ditentukan.

Pengertian supervisi sangat luas, sebagaimana disebutkan DRS, M. Ngalim Purwanto (2010). supervisi adalah segala bantuan dari para pemimpin sekolah yang tertuju kepada prkembangan kepemimpinan guru-guru dan personel sekolah lainnya di dalam mencapai tujuan-tujuan pendidikan. Selanjutnya disebutkan, dengan kata lain supervisi ialah suatu aktivitas pembinaan yang direncanakan untuk membantu para gurudan pegawai 
sekolah lainnya dalam melakukan pekerjaan mereka secara efektif. Secara harfiah kata supervisi sama dengan membangun, meningkatkan atau memperbaiki (Wojowasito, 1980).

Dalam kegiatan sehari-hari di sekolah kata supervisi selalu diartikan dengan supervisi pengajaran. Menurut penjelasan UUSPN Tahun 2003 UUSPN Pasal 52 kata supervisi dimasukan dalam rangkaian kata supervisi, yaitu "pengawas lebih merupakan upaya untuk memberikan bimbingan supervisi, dorongan, dan pengayoman bagi satuan pendidikan yang bersangkutan yang diharapkan terus-menerus dapat terus meningkatkan mutu pendidikan maupun pelayanannya". Dalam Carter Good Goveremance Dictionary of Education mengemukakan bahwa supervisi adalah segala usaha pejabat dalam memimpin guru-guru dan tenaga kependidikan lainnya, untuk memperbaiki pengajaran, termasuk menstimulasi, menyeleksi pertumbuhan dan jabatan-jabatan guru-guru, menyeleksi dan merevisi tujuan-tujuan pendidikan, bahan pengajaran dan metode-metode mengajar serta evaluasi pengajaran.

Boardman menyebutkan supervisi adalah salah satu usaha menstimulir, mengkoordinir dan membimbing secarr kontinyu pertumbuhan guru-guru di sekolah baik secara individual maupun secara kolektif, agar lebih mengerti dan lebih efektif dalam mewujudkan seluruh fungsi pengajaran dengan demikian mereka dapat menstmulir dan membimbing pertumbuan tiap-tiap murid secara kontinyu, serta mampu dan lebih cakap berpartsipasi dlm masyarakat demokrasi modern. Wilem Mantja (2007) mengatakan bahwa, supervisi diartikan sebagai kegiatan supervisor (jabatan resmi) yang dilakukan untuk perbaikan proses belajar mengajar (PBM). Ada dua tujuan (tujuan ganda) yang harus diwujudkan oleh supervisi, yaitu; perbaikan (guru murid) dan peningkatan mutu pendidikan. Willem Mantja memandang supervisi sebagai kegiatan untuk perbaikan (guru murid) dan peningkatan mutu pendidikan Mulyasa (2006)
Supervisi sesungguhnya dapat dilaksanakan oleh kepala sekolah yang berperan sebagai supervisor, tetapi dalam sistem organisasi modern diperlukan supervisor khusus yang lebih independent, dan dapat meningkatkan obyektivitas dalam pembinaan dan pelaksanaan tugas.

\subsection{Tujuan Supervisi Pendidikan}

Tujuan utama supervisi adalah memperbaiki pengajaran (Neagly \& Evans, 1980; Oliva, 1984; Hoy \& Forsyth, 1986; Wiles dan Bondi, 1986; Glickman, 1990). Tujuan umum supervisi adalah memberikan bantuan teknis dan bimbingan kepada guru dan staf agar personil tersebut mampu meningkatkan kualitas kinerjanya, dalam melaksanakan tugas dan melaksanakan proses belajar mengajar. Secara operasional dapat dikemukakan beberapa tujuan konkrit dari supervisi pendidikan yaitu :

a. Meningkatkan mutu kinerja guru

b. Membantu guru dalam memahami tujuan pendidikan dan apa peran sekolah dalam mencapai tujuan tersebut

c. Membantu guru dalam melihat secara lebih jelas dalam memahami keadaan dan kebutuhan siswanya.

d. Membentuk moral kelompok yang kuat dan mempersatukan guru dalam satu tim yang efektif, bekerjasama secara akrab dan bersahabat serta saling menghargai satu dengan lainnya.

e. Meningkatkan kualitas pembelajaran yang pada akhirnya meningkatkan prestasi belajar siswa.

f. Meningkatkan kualitas pengajaran guru baik itu dari segi strategi, keahlian dan alat pengajaran.

\subsection{Sasaran Supervisi}

Adapun sasaran utama dari pelaksanaan kegiatan supervisi tersebut adalah peningkatan kemampuanprofesional guru (Depdiknas, 
1986; 1994 \& 1995). Sasaran Supervisi

Ditinjau dari objek yang disupervisi, ada 3 macam bentuk supervisi :

a. Supervisi Akademik, Menitikberatkan pengamatan supervisor pada masalahmasalah akademik, yaitu hal-hal yang berlangsung berada dalam lingkungan kegiatan pembelajaran pada waktu siswa sedang dalam proses mempelajari sesuatu

b. Supervisi Administrasi, Menitikberatkan pengamatan supervisor pada aspek-aspek administrasi yang berfungsi sebagai pendukung dan pelancar terlaksananya pembelajaran.

c. Supervisi Lembaga, Menyebarkan objek pengamatan supervisor pada aspek-aspek yang berada di sekolah. Supervisi ini dimaksudskan untuk meningkatkan nama baik sekolah atau kinerja sekolah secara keseluruhan. Misalnya: Ruang UKS (Unit Kesehatan Sekolah), Perpustakaan dan lain-lain.

\subsection{Prinsip-prinsip Supervisi}

Prinsip-prinsip supervisi menurut Sahertian (1981)

a. Prinsip ilmiah (scientific), prinsip ini mengandung ciri-ciri sebagai berikut: (a) kegiatan supervisi dilaksanakan berdasarkan data objektif yang diperoleh dalam kenyataan pelaksanaan proses belajar mengajar. (b) untuk memperoleh data perlu diterapkan alat perekam data, seperti angket, observasi, percakapan pribadi, dan seterusnya. (c) setiap kegiatan supervisi dilaksanakan secara sistematis, berencana dan kontinu.

b. Prinsip Demokratis, servis dan bantuan yang diberikan kepada guru berdasarkan hubungan kemanusiaan yang akrab dan kehangatan sehingga guru-guru merasa aman untuk mengembangkan tugasnya.

c. Prinsip kerjasama, mengembangkan usaha bersama atau menurut istilah supervisi 'sharing of idea, sharing of experience', memberi support atau mendorong, menstimulasi guru, sehingga mereka merasa tumbuh bersama.

d. Prinsip konstruktif dan kreatif, setiap guru akan merasa termotivasi dalam mengembangkan potensi kreativitas kalau supervisi mampu mencipakan suasana kerja yang menyenangkan, bukan melalui caracara yang menakutkan.

Secara sederhana prinsip-prinsip Supervisi adalah sebagai berikut ini.

a. Supervisi hendaknya memberikan rasa aman kepada pihak yang disupervisi.

b. Supervisi hendaknya bersifat Kontrukstif dan Kreatif

c. Supervisi hendaknya realistis didasarkan pada keadaan dan kenyataan sebenarnya.

d. Kegiatan supervisi hendaknya terlaksana dengan sederhana.

e. Dalam pelaksanaan supervisi hendaknya terjalin hubungan profesional, bukan didasarkan atas hubungan pribadi.

f. Supervisi hendaknya didasarkan pada kemampuan, kesanggupan, kondisi dan sikap pihak yang disupervisi.

g. Supervisi harus menolong guru agar senantiasa tumbuh sendiri tidak tergantung pada kepala sekolah

\section{PEMBAHASAN}

\section{Pelaksanaan Supervisi Pendidikan dalam menunjang Kinerja Guru di TK islam Tirtayasa Serang}

Kegiatan supervisi pendidikan di TK Islam Tirtayasa Serang dilaksanakan secara rutin. Pelaksanaannya cukup beragam. Adakalanya Kepala Sekolah mengunjungi kelas atau guruguru dikumpulkan dalam suatu ruangan. Supervisi yang dilakukan lebih kepada memberikan bimbingan kepada para guru bukan mencari-cari kesalahan para guru. 
Melalui arahan dan bimbingan ini diharapkan kinerja guru dapat meningkat.

Berdasarkan hasil wawancara dengan kepala sekolah, serta studi dokumentasi di TK Islam Tirtayasa, kegiatan supervisi dilakukan antara lain sebagai berikut ini.

\section{Kunjungan Kelas}

Kepala sekolah datang ke kelas untuk melihat cara guru mengajar di kelas. Tujuannya dari perkunjungan kelas adalah untuk memperoleh data mengenai keadaan sebenarnya selama guru mengajar. Supervisor dapat berbincangbincang dengan guru tentang kesulitan yang dihadapi guru-guru. Selain itu selama kunjungan kelas kepala sekolah dan antara lain dapat :

a. Mempelajari kekuatan dan kelemahan pelaksanaan kegiatan pembelajaran untuk pengembangan dan pembinaan lebih lanjut dan mengidentifikasikan kendala yang dihadapi sewaktu melaksanakan suatu pembaharuan pengajaran

b. Secara langsung mengetahui keperluan guru dan siswa dalam melaksanakan suatu gagasan belajar mengajar secara efektif

c. Memperoleh sejumlah informasi untuk menyusun program pembinaan profesional secara terinci

d. Menumbuhkan sikap percaya diri guru untuk berbuat dan melaksanakan pembelajaran yang lebih baik

e. Sebagai alat untuk mendorong guru agar meningkatkan cara mengajar guru dan cara belajar siswa.

Jenis - Jenis kunjungan yang dilakukan kepala Sekolah kadang-kadang tanpa diberi tahu (unannounced visitation) atau kunjungan dengan cara diberi tahu lebih dulu (announced visitation) atau bisa juga kunjungan atas undangan guru (visit upon invitation) Melalui kunjungan kelas kepala sekolah ,dapat mengobservasi situasi belajar-mengajar yang sebenarnya. Tujuan observasi untuk memperoleh data yang subjektif. Bagi guru sendiri dapat membantu untuk mengubah caracara mengajar ke arah yang lebih baik. Bagi murid-murid dapat menimbulkan pengaruh positif terhadap kemajuan belajar mereka. Halhal yang perlu di observasi usaha serta kegiatan guru dan murid dan Lingkungan sosial, fisik sekolah, baik di dalam maupun di luar kelas. Melalui kunjungan kelas ini diharapkan dapat menunjang peningkatan kinerja para guru di TK Islam Tirtayasa.

\section{Rapat guru}

Rapat Guru adalah teknik supervisi kelompok melalui rapat guru yang dilakukan untuk membicarakan proses pembelajaan, dan upaya atau cara meningkatkan profesi guru. Tujuan teknik supervisi rapat guru yang dilakukan di TK Islam Tirtayasa adalah sebagai berikut ini .

a. Menyatukan pandangan - pandangan guru tentang masalah - masalah dalam mencapai makna dan tujuan pendidikan.

b. Memberikan motivasi kepada guru untuk menerima dan melaksanakan tugas - tugasnya dengan baik serta dapat mengembangkan diri dan jabatan mereka secara maksimal.

c. Menyatukan pendapat tentang metode kerja yang baik guna pencapaian pengajaran yang maksimal.

d. Membicarakan sesuatu melalui rapat guru yang bertalian dengan proses pembelajaran.

e. Menyampaikan informasi baru seputar belajar dan pembelajaran, kesulitan kesulitan mengajar, dan cara mengatasi kesulitan mengajar secara bersama dengan semua guru disekolah.

\section{Diskusi}

Diskusi adalah pertukaran pikiran atau pendapat melalui suatu percakapan tentang suatu masalah untuk mencari alternatif pemecahannya. Diskusi merupakan salah satu 
teknik supervisi kelompok yang digunakan kepala sekolah untuk mengembangkan berbagai ketrampilan pada diri para guru dalam mengatasi berbagai masalah atau kesulitan dengan cara melakukan tukar pikiran antara satu dengan yang lain. Melalui teknik ini supervisor dapat membantu para guru untuk saling mengetahui, memahami, atau mendalami suatu permasalahan, sehingga secara bersama - sama akan berusaha mencari alternatif pemecahan masalah tersebut .Tujuan pelaksanaan supervisi diskusi adalah untuk memecahkan masalah - masalah yang dihadapi guru dalam pekerjaannya sehari - hari dan upaya meningkatkan profesi melaluii diskusi.

Hal - hal yang menjadi perhatian kepala sekolah sebagai pemimpin diskusi sehingga setiap anggota mau berpartisipasi selama diskusi berlangsung kepala sekolah TK Islam Tirtayasa berupaya :

a. Menentukan tema perbincangan yang lebih spesifik

b. Melihat bahwa setiap anggota diskusi senang dengan keadaan dan topik yang dibahas dalam diskusi.

c. Melihat bahwa masalah yang dibahas dapat dimengerti oleh semua anggota dan dapat memecahkan masalah dalam pengajaran.

d. Melihat bahwa kelompok merasa diperlukan dan diikutsertakan untuk mencapai hasil bersama.

e. Mengakui pentingnya peranan setiap anggota yang dipimpinnya.

Melalui diskusi yang rutin dilakukan ini diharapkan dapat meningkatkan wawasan para guru khususnya dalam peningkatan profesional guru di TK Islam Tirtayasa Serang.

\section{Workshop}

Workshop adalah suatu kegiatan belajar kelompok yang terjadi dari sejumlah pendidik yang sedang memecahkan masalah melalui percakapan dan bekerja secara kelompok.Pada kegiatan workshop ini , di TK Islam Tirtayasa diketuai oleh Kepala Sekolah. Kepala sekolah yang memimpin kegiatan workshop tersebut. Hal - hal yang menjadi perhatian pada waktu pelaksanaan workshop antara lain :

a. Masalah yang dibahas bersifat "life centred" dan muncul dari guru tersebut,

b. Selalu menggunakan secara maksimal aktivitas mental dan fisik dalam kegiatan sehingga tercapai perubahan profesi yang lebih tinggi dan lebih baik.

\section{Tukar menukar pengalaman Tukar menukar pengalaman "Sharing of Experince"}

Ini suatu teknik perjumpaan dimana guru menyampaikan pengalaman masing-masing dalam mengajar terhadap topik-topik yang sudah diajarkan, saling memberi dan menerima tanggapan dan saling belajar satu dengan yang lain. Langkah - langkah melakukang sharing antara lain :Menentukan tujuan yang akan dicapai.Menentukan pokok masalah yang akan dibahas.Memberikan kesempatan pada setiap peserta untuk menyumbangkan pendapat pendapat merekaMerumuskan kesimpulan.

Kegiatan ini biasanya dilakukan apabila guru yang bersangkutan telah mengikuti suatu pelatihan atau kegiatan ilmiah lainnya.

\section{Percakapan Pribadi}

Percakapan pribadi merupakan Dialog yang dilakukan oleh guru dan kepala sekolahnya, yang membahas tentang keluhan - keluhan atau kekurangan yang dikeluarkan oleh guru dalam bidang mengajar, di mana di sini kepala sekolah dapat memberikan jalan keluarnya. Dalam percakapan ini kepala sekolah berusaha menyadarkan guru akan kelebihan dan kekurangannya. mendorong agar yang sudah baik lebih di tingkatkan dan yang masih kurang atau keliru agar diupayakan untuk memperbaikinya.Percakapan ini sifatnya tertutup, artinya guru lain tidak mengetahui percakapan antara kepala sekolah dengan guru yang bersangkutan. 


\section{Intervisitasi (mengunjungi sekolah lain)}

Teknik ini dilakukan untuk sharing dengan sekolah lain yang ada di Serang. Caranya dengan menyuruh beberapa orang guru untuk mengunjungi sekolah - sekolah yang ternama dan maju dalam pengelolaannya untuk mengetahui kiat - kiat yang telah diambil sampai seekolah tersebut maju. Manfaat yang dapat diperoleh dari teknik supervisi ini adalah dapat saling membandingkan dan belajar atas kelebihan dan kekurangan berdasarkan pengalaman masing masing. Sehingga masing masing guru dapat memperbaiki kualitasnya dalam memberi layanan belajar kepada peserta didiknya.

\section{Penyeleksi berbagai sumber materi untuk mengajar}

Pelaksanaan supervisi ini berkaitan dengan aspek - aspek belajar mengajar. Dalam usaha memberikan pelayanan profesional kepada guru, Kepala sekolah akan menaruh perhatian terhadap aspek - aspek proses belajar mengajar sehingga diperoleh hasil yang efektif. Dalam hal ini, kepala sekolah harus mempunyai kemampuan menyeleksi berbagai sumber materi yang digunakan guru untuk mengajar. Hal ini seringkali dilakukan oleh kepala sekolah TK islam Tirtayasa . Kepala sekolah menyeleksi buku - buku yang dimiliki oleh guru pada saat mengajar yang sesuai dengan kebutuhan kegiatan belajar mengajar.

\section{Menilai diri sendiri}

Guru dan kepala sekolah melihat kekurangan masing-masing yang mana ini dapat memberikan nilai tambah pada hubungan guru dan kepala sekolah tersebut,yang akhirnya akan memberikan nilai positif bagi kegiatan belajar mengajar yang baik. Menilai diri sendiri merupakan tugas yang tidak mudah bagi guru, karena suatu pengukuran terbalik karena selama ini guru hanya menilai muridmuridnya. Ada beberapa cara atau alat yang dapat digunakan untuk menilai diri sendiri, antara lain membuat daftar pandangan atau pendapat yang disampaikan kepada muridmurid untuk menilai pekerjaan atau suatu aktivitas guru di muka kelas. Yaitu dengan menyususun pertanyaan yang tertutup maupun terbuka, tanpa perlu menyebutkan nama siswa.

Setelah dilaksanakannya supervisi pendidikan oleh kepala sekolah di TK Islam Tirtayasa ada peningkatan kinerja , sebagai indikatornya ada peningkatan kompetensi dalam bidang pedagogik, kepribadian, sosial dan profesional.

Pada aspek pedagogik, guru-guru menguasai hal-hal berikut ini.

a. Karakteristik peserta didik,

b. Teori belajar dan prinsip-prinsip pembelajaran yang mendidik

c. Pengembangan kurikulum

d. Kegiatan pembelajaran yang mendidik

e. Memahami dan mengembangkan potensi.

f. Komunikasi dengan peserta didik.

g. Penilaian dan evaluasi

Pada Aspek Kepribadian, guru-guru memiliki kompetensi sebagai berikut ini.

a. Bertindak sesuai dengan norma agama, hukum, sosial, dan kebudayaan nasional Indonesia.

b. Menunjukan pribadi yang dewasa dan teladan.

c. Etos kerja, tanggung jawab yang tinggi dan rasa bangga menjadi guru.

Pada aspek sosial, guru-guru :

a. Bersikap inklusif, bertindak objektif serta tidak diskriminatif

b. Komunikasi dengan sesama guru, tenaga kepedidikan, orang tua dan masyarakat

Pada aspek profesioanl kompetensi yang dimiliki guru-guru yakni :

a. Penguasan materi struktur konsep dan pola fikir keilmuan yang mendukung mata pelajaran yang diampu. 
b. Mengembangkan keprofesian melalui tindakan reflektif.

Setelah dilakukan penilaian terhadap kinerja guru di TK Islam Tirtayasa rata-rata sangat baik. Dengan total nilai 56.

\section{KESIMPULAN DAN SARAN}

Pelaksanaan supervisi pendidikan oleh Kepala Sekolah Tk Islam Tirtayasa Serang ternyata cukup efektif. Ada perubahan kinerja guru yang cukup baik.Kegiatan supervisi dilaksanakan secara rutin dan terprogram .Bentuk supervisi cukup beragam diantaranya : kunjungan kelas, rapat guru, diskusi, workshop, tukar menukar pengalaman , kunjungan ke sekolah lain, menyeleksi bahan ajar, dan menilai diri sendiri.

Kegiatan-kegiatan supervisi tersebut dapat menunjang kinerja guru di TK islam Tirtayasa, terbukti dengan penilaian kinerja yang dilakukan terhadap guru-guru hasilnya sangat baik.

Sebaiknya kegiatan supervisi ini dilaksanakan secara terus menerus, walaupun hasil penilaian kinerja sudah sangat baik. Adakalanya manusia itu berubah, tanpa bimbingan atau arahan kadang kembali lagi ke semula. Dikawatirkan kinerjanya rendah lagi apabila tanpa adanya pembinaan dari kepala sekolah.

\section{DAFTAR PUSTAKA}

Afifuddin,dkk. (2005). Administrasi Pendidikan. Bandung: CV. Insan Mandiri

Ametembun, N.A. (1981). Guru dalam administrasi sekolah. Bandung: IKIP Bandung
Arikunto, Suharsimi. (2004). Dasar-Dasar Supervisi. Jakarta: PT Rineka Cipta.

Atmosudirdjo, Prajudi S. (1985). Dasar-dasar ilmu administrasi. Jakarta: PT. Ghalia Indonesia.

Echols, John, M, Shadily, Hassan. (1983). Kamus Bahasa Inggris Indonesia. Jakarta: PT. Gramedia

Hasan, Yusuf, dkk., (2002). Pedoman Pengawasan, Jakarta: CV. Mekar Jaya.

Jasmani dkk. (2013). Supervisi Pendidikan Terobosan Baru dalam Peningkatan Kinerja Pengawas Sekolah dan Guru, Yogyakarta: Ar Ruzz Media.

A. Sahertian, Piet, Drs.( 1981) Prinsip dan Teknik Supervisi Pendidikan, Usaha Nasional: Surabaya.

Ma'mur, J.A. (2012). Tips Efektif Supervisi Pendidikan Sekolah, Yogyakarta, Diva Press.

Pidarta, Made. (2009). Manajemen Pendidikan Indonesia. Bandung, PT. Bina Aksana.

Purwanto, Ngalim. (2010). Administrasi dan Supervisi Pendidikan. Bandung, PT. Remaja Rosdakarya.

Rifai, Mohd. (1987). Administrasi dan Supervisi Pendidikan. Bandung, Jemmars.

Sahertian. A Piet. (1994). Profil Pendidik Profesional. Yogyakarta, Adni Offset.

Sutisna, Oteng. (1983). Administrasi Pendidikan. Bandung, Aksara.

Wiles, Kimball. (1987). Supervision for Better School. New Yersey, Printice Hall Inc, Engwwood Cliffs,. 